\title{
Sciendo
}

RURAL SUSTAINABILITY RESEARCH 45 (340), 2021

ISSN - 2256-0939

(c) Latvia University of Life Sciences and Technologies, all rights reserved http://www.llu.Iv/en/

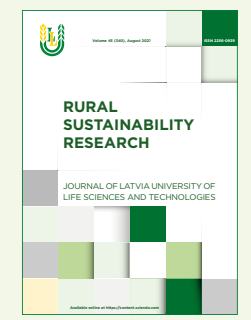

Received: 10 November 2020

Revised: 30 November 2020

Accepted: 31 March 2021

\section{The Influence of Technological Peculiarities on Fermented Sausages' Quality and Sensory Properties}

\author{
*Ilze Gramatina ${ }^{1}$, Janis Sauka², Aleksandrs Semjonovs ${ }^{2}$, Sintija Strode ${ }^{1}$, Evita Straumite ${ }^{1}$ \\ ${ }^{1}$ Latvia University of Life Sciences and Technologies, 2 Liela street, Jelgava, Latvia \\ ${ }^{2}$ Ādažu desu darbnīca Ltd., 9 Gaujas street, Adazi, Latvia
}

\begin{abstract}
Fermentation is one of the ancient technological processes used in food production which influences the shelf-life of meat and meat products, also significantly affects the sensory properties like aroma and flavour. The objective of the present study was to evaluate the elaborated technology for a new fermented sausage production on the product quality and sensory properties. Sausages were produced by the standard technology using glucono-delta-lactone or starter culture. The drying of samples differs from 3 to 4 weeks at the same conditions; samples were dried for 4 weeks which produced with the starter culture, and 3 weeks which produced with glucono-delta-lactone. The sausages were tested at the end of the production, analysing $\mathrm{pH}$, water activity, moisture and salt content, as well as the presence of Listeria monocytogenes, colony forming units of Listeria monocytogenes and Enterobacteriaceae in the sausage samples were analysed. The sensory evaluation was organised after getting Listeria monocytogenes testing results.

The moisture content, water activity and salt content significantly differed $(\mathrm{p}<0.05)$ among samples, no differences were established in $\mathrm{pH}$, taste and flavour liking. The presence of Listeria monocytogenes was not established in samples which indicates that the producer properly applies a hurdle technology in fermented sausage production.

Sensory evaluation results showed higher scores for texture and appearance in fermented sausages with glucono-delta-lactone. The study results confirmed that fermented sausages with glucono-delta-lactone during 3 weeks of drying can achieve corresponding safety criteria and sensory properties which are set for semidry fermented sausages.
\end{abstract}

Key words: Listeria monocytogenes, fermentation, fermented sausages, physicochemical parameters, sensory evaluation.

\section{Introduction}

Fermentation is one of the ancient technological processes used in food production which influences the shelf-life of meat and meat products, also significantly affects the sensory properties like aroma and flavour. During fermentation, biochemical and microbiological reactions occur, and enzymes and microflora of raw materials and ingredients used for fermented sausages production, as well as the technological process parameters (Prado et al., 2019) play the main role.

Listeria monocytogenes is of a particular concern for fermented sausages' production and may cause serious health problems to consumers. Listeria monocytogenes is difficult to control in fermented sausages production due to its high tolerance to low $\mathrm{pH}$ and high salt content (Brusa et al., 2020). The frequent detection of Listeria monocytogenes in these products highlights the necessity for food business operators to properly apply hurdle technology and control the contamination routes of Listeria monocytogenes in the processing plants (Meloni, 2015). During fermentation and drying, the activity of Listeria monocytogenes in semidry and dry fermented sausages substantially diminishes (Thevenot et al., 2005) due to intercombination of several factors such as $\mathrm{pH}$, water activity, lactic acid bacteria metabolites, as well as a viability of lactic acid bacteria.

\footnotetext{
* Corresponding Author's email:

Ilze.Gramatina@1lu.lv
} 
Semidry and dry fermented sausages are characterized with the long shelf-life, it is established by the traditional production process using lactic acid bacteria and other microflora as well as high salt content. Lactic acid fermentation changes sausage $\mathrm{pH}$ and diminishes the water activity. The $\mathrm{pH}$ and water activity are crucial parameters for semidry and dry fermented sausages' safety (Mataragas et al., 2015; Tirloni et al., 2019). In the compliance with the requirements of European Commission Regulation 2073/2005, when ready-to-eat food products (fermented sausages) are unable to support the growth of Listeria monocytogenes, a criteria of $<$ $100 \mathrm{CFU} \mathrm{g}^{-1}$ should be applied, as well as the absence of Listeria monocytogenes in $25 \mathrm{~g}$ of fermented sausages is compulsory (EC, 2005).

Fermented sausages have long production traditions in Europe. In the development of new fermented sausages, a traditional production technology is applied with or without application of starter cultures. There is an industrial interest for the production of such products (Prado et al., 2019) and knowing the microbial diversity in fermented sausages, it gives a possibility to improve the safety criteria as well as unique sensory properties of fermented sausages. Although the drying time is crucial for sensory properties formation, the length of drying process significantly influences the production costs too. The objective of the present study was to evaluate the elaborated technology of the new fermented sausage production on the product quality and sensory properties.

\section{Materials and Methods}

Fermented sausages were produced according to the standardized process in the processing company using two different approaches for insurance of sausage quality and sensory properties.

The experiment was conducted using the following ingredients: pork and beef meat, blend of spices (spices and spice extracts), dextrose, nitrite salt, flavour additives (smoke aroma, etc.). Two experimental series were made for applying the corresponding quality and safety criteria, as well as the appropriate sensory properties of sausages. In the first series, the starter culture was added to meat before filling. The starter consists of Staphylococcus carnosus, Kocuria salsicia, Lactobacillus casei (Bitec starter B2, Frutarom, Germany). In the second series, the glucono-deltalactone (E575) was added to meat in $0.8 \%(\mathrm{w} / \mathrm{w})$ prior filling. The raw sausages were stuffed into natural casings.

The production process involves following steps: selection of ingredients, meat grinding and mixing of ingredients, addition of starter culture or glucono-deltalactone, filling, cold smoking, and drying of samples at the controlled conditions: temperature $14-18^{\circ} \mathrm{C}$, relative humidity $76 \% .1^{\text {st }}$ series products are produced by accomplishment of natural microflora, but $2^{\text {nd }}$ series products by starter culture, as well as $1^{\text {st }}$ series samples dried 3 weeks, but $2^{\text {nd }}$ series samples -4 weeks. The main reason for longer drying time was peculiarities in the flavour compounds formation due to slower growing of starter bacteria in sausage media.

The sausages were tested at the end of the production, analysing $\mathrm{pH}$, water activity, moisture and salt content, as well as the presence of Listeria monocytogenes, colony forming units of Listeria monocytogenes and Enterobacteriaceae in the sausage samples were analysed. The sensory evaluation was organised after getting of Listeria monocytogenes testing results.

pH was measured according to ISO 2917:1999 standard, using $\mathrm{pH}$-meter Jenway (Barlword Scientific Ltd., UK). Water activity was analysed according to ISO 21807:2004 standard, using Lab Swift - aw (Novasina, Switzerland) device. Moisture content was analysed according to ISO 1442:1997 standard, using Memmert UF 55 (Memmert, Germany) incubator. Salt content was detected according to the Mohr's method. All samples were analysed in triplicate.

The detection of Listeria monocytogenes was estimated according to ISO 11290-1:2017 standard and the enumeration of Listeria monocytogenes was analysed according to ISO 11290-2:20017 standard, as well as the presence of Enterobacteriaceae was tested correspondingly to ISO 21528-2:2017 standard. The microbiological analysis was carried out in the authorized laboratory for food quality control (Auctoritas laboratorija, Ltd).

The sensory evaluation of fermented sausages was realised according to ISO 4121:2003 standard. A five point hedonic scale was used to determine the degree of liking, where: 1 - dislike extremely; 2 - dislike a little; 3 - neither like nor dislike; 4 - like a little; 5 - like extremely. The fermented sausage samples were evaluated by 41 trained panellists comprising the students and an academic staff of the Faculty of Food Technology.

Statistical analysis was performed using one-way of analysis of variance and differences were considered statistically significant at a confidence level of $p<0.05$. The sensory data were analysed using two-way analysis of variance and Tukey's test.

\section{Results and Discussion}

Fermented sausages produced in Latvia are made from pork and bacon, with addition of beef, nitrite salt, and pepper, spices, glucono-delta-lactone and starter culture. After mixing, meat is stuffed into casing and sausages are fermented and dried differently. The drying affects the physicochemical parameters of analysed samples, Table 1. 
Moisture content. Analysing moisture content in $1^{\text {st }}$ series products, it is considered that they belong to semidry fermented sausages, but $2^{\text {nd }}$ series sausages belong to dry fermented sausages. The lower moisture content in $2^{\text {nd }}$ series sausages indicates to the higher water loss during drying process. The results showed that there were significant differences $(p=0.010)$ in the moisture content between the analysed samples. The results showed a relationship between the moisture content of fermented sausage samples and the duration of drying, as well as salt content.

The physicochemical parameters of fermented sausage samples

Table 1

\begin{tabular}{|c|c|c|c|}
\hline Samples & Moisture, $\%$ & $\boldsymbol{p H}$ & Salt content, $\%$ \\
\hline $1^{\text {st }}$ series & $39.00 \pm 0.03$ & $4.73 \pm 0.00$ & $3.89 \pm 0.00$ \\
\hline $2^{\text {nd }}$ series & $28.50 \pm 0.24$ & $4.72 \pm 0.01$ & $4.55 \pm 0.13$ \\
\hline
\end{tabular}

$p H$. Acidity of sausages impacts on the fermentative ability of sausage microflora or added starter culture. A sufficient level of acidification in $1^{\text {st }}$ series samples had been achieved by the addition of gluconodelta-lactone. However, glucone-delta-lactone was added in $0.8 \%$ (w/w), according to the meat processing professionals view (Feiner, 2006), this concentration is quite high. The high rate of acidification does not permit the process of denitrification performed by microorganisms. Between $1^{\text {st }}$ and $2^{\text {nd }}$ series samples, there are no significant differences $(\mathrm{p}=0.205)$ in $\mathrm{pH}$, they are practically identical. Semidry sausages $\mathrm{pH}$ is usually ranged between 4.80 and 5.20 (Ricke \& Keeton, 1997). A pH of 4.8 or below influences the taste, but does not contribute to the formation of better structure properties in the final product (FAO, 2013). The $\mathrm{pH}$ of dry sausages is higher (5.0-5.5) than in semidry sausages and the increase of $\mathrm{pH}$ continues during the drying process (Lazic et al., 2019; FAO, 2013; Silins, 2014). Analysed sausages were dried only for 4 weeks which is a short time for such products production. If the producer had prolonged the sausages drying, it would have reflected on product $\mathrm{pH}$ and sausages would have reached desirable $\mathrm{pH}$ for dry fermented sausages. However, low $\mathrm{pH}$ gives the fermented sausages excellent keeping quality.

Salt content. The results showed that the differences are not significant $(\mathrm{p}=0.086)$ between analysed samples. A close relationship has been observed between the moisture and salt content in the samples. We noticed that the longer drying process had provided the greater loss of moisture and, consequently, the increasing of the total solids as well as the salt content. This observation is in an agreement with the data set in the sensory evaluation, which showed the lower degree of liking in the taste evaluation of $2^{\text {nd }}$ series samples. Consumers gave preference to the taste of $1^{\text {st }}$ series samples $(4.10 \pm 0.83)$, which had showed the lower salt content. However, $2^{\text {nd }}$ series samples' results $(3.95 \pm 0.77)$ had not showed the significant differences in the taste evaluation, comparing to $1 \mathrm{st}$ series samples.

In order to achieve safety criteria, it is of importance to provide the proper growth conditions of starter lactic acid bacteria or desirable sausages microflora. Listeria monocytogenes, Enterobacteriaceae and water activity (aw) data were summarized in Table 2.

Listeria monocytogenes, Enterobacteriaceae and water activity $\left(a_{w}\right)$ in fermented sausage samples

\begin{tabular}{|c|c|c|}
\hline Indices & $\mathbf{1}^{\text {st }}$ series samples & $2^{\text {nd }}$ series samples \\
\hline Listeria monocytogenes & $\begin{array}{c}\text { absent in } 25 \mathrm{~g} \\
<100 \mathrm{CFU} \mathrm{g}{ }^{-1}\end{array}$ & $\begin{array}{c}\text { absent in } 25 \mathrm{~g} \\
<100 \mathrm{CFU} \mathrm{g}^{-1}\end{array}$ \\
\hline Enterobacteriaceae & $<10 \mathrm{CFU} \mathrm{g}^{-1}$ & $<10 \mathrm{CFU} \mathrm{g}^{-1}$ \\
\hline Water activity & $0.834 \pm 0.003^{\mathrm{a}}$ & $0.804 \pm 0.004^{\mathrm{b}}$ \\
\hline
\end{tabular}

$a b$ - means with the same line followed by different letter at $p<0.05$ 
No Listeria monocytogenes was detected in both series samples, and the microbiological evaluation results confirmed the effectiveness of the quality management system in the processing plant. Water activity, smoke compounds and accumulated fermentation metabolites mainly acids, aldehydes and esters have the influence on quality and safety criteria of produced sausages, as well as they are prerequisites for sausages storage ability. In addition to low $\mathrm{pH}$, salt acts as one of the first hurdles, inhibiting the growth of potential contaminants and pathogens. Water activity values in sausages on the day 21 (3 weeks of drying) and day 28 (4 weeks of drying) were respectively 0.834 and 0.804 . Such values are an important hurdle in sausages for Listeria monocytogenes survival with $\mathrm{a}_{\mathrm{w}}$ inhibiting level below 0.92 (Lucke, 1985; Stiebing \& Rödel, 1988; Thevenot et al., 2005).

Sensory properties as an appearance, flavour, structure and taste of fermented sausages were evaluated (Figure 1).

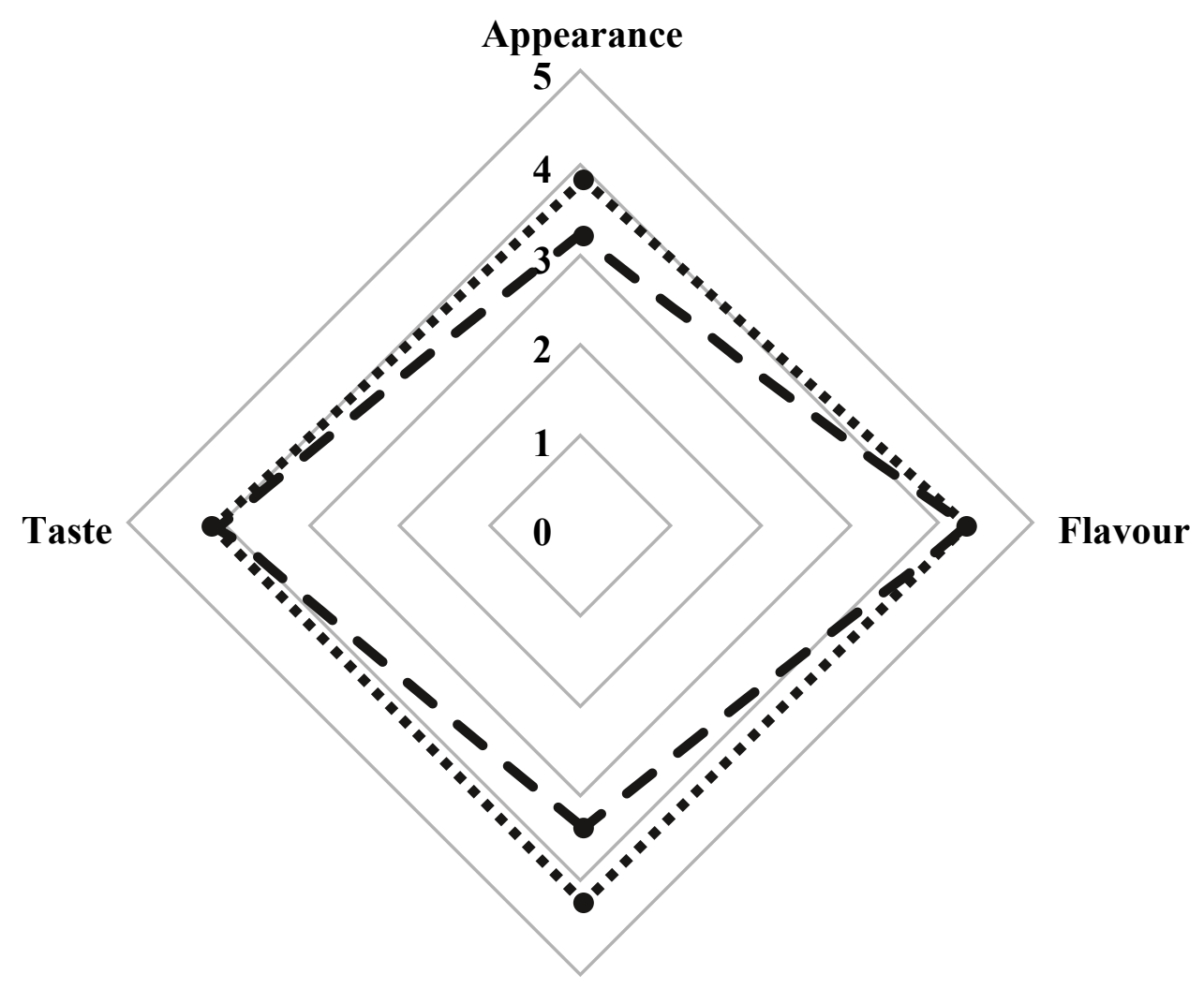

Structure

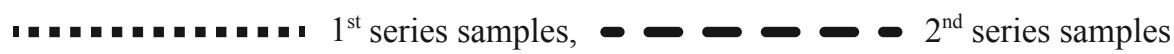

Figure 1. The degree of liking of fermented sausage samples.

The sensory attributes of evaluated samples are shown in Table 3.

Table 3

Sensory attributes value ( \pm standard deviation) of sausage samples

\begin{tabular}{|c|c|c|c|c|}
\hline Samples & Appearance & Flavour & Structure & Taste \\
\hline $1^{\text {st }}$ series & $3.83 \pm 0.83^{\mathrm{a}}$ & $4.20 \pm 0.93^{\mathrm{a}}$ & $4.17 \pm 0.70^{\mathrm{a}}$ & $4.10 \pm 0.83^{\mathrm{a}}$ \\
\hline $2^{\text {nd }}$ series & $3.20 \pm 0.93^{\mathrm{b}}$ & $4.34 \pm 0.82^{\mathrm{a}}$ & $3.32 \pm 0.88^{\mathrm{b}}$ & $3.95 \pm 0.77^{\mathrm{a}}$ \\
\hline
\end{tabular}

$a b$ - means with the same column followed by different letter at $p<0.05$ 
There were no established significant differences in flavour $(\mathrm{p}=0.453)$ and taste $(\mathrm{p}=0.412)$ evaluation between the samples whereas there were established significant differences between the samples in appearance $(p=0.002)$ and structure $(p=0.000)$ evaluation. We can conclude that the technological peculiarities of the production of fermented sausages have affected the appearance and structure, but these changes did not significantly influence the taste of samples.

Appearance. The evaluation of the appearance of $1^{\text {st }}$ series samples reaches $3.83 \pm 0.83$, which was "neither like nor dislike" to "like a little" scale. It should be noted that the assessment of the degree of appearance liking of $2^{\text {nd }}$ series samples was also in the hedonic scale from "neither like nor dislike" to "like a little" (mean $3.20 \pm 0.93$ ). As it turned out, there are significant differences between the samples in terms of the assessment of the degree of liking for appearance. In addition, the panellists indicated that the colour of evaluated samples had differed, and they gave preference to $2^{\text {nd }}$ series samples. These differences we could explain with the high doses of glucono-deltalactone which was added in 1st series samples making sausages colour and appearance slightly grey.

Flavour. There are no significant differences between the samples in terms of evaluation of the degree of flavour liking; the evaluators liked both samples equally well. The flavour rating of $1^{\text {st }}$ series samples is $4.20 \pm$ 0.93 and $2^{\text {nd }}$ series samples is $4.34 \pm 0.82$, respectively, within the hedonic scale range from "like a little" to "like extremely". Starter cultures play an important role in the fermented products production; they can inhibit the growth of pathogenic bacteria and promote the development of sensory properties such as colour, texture and flavour (Hu et al., 2020; Tabanelli et al., 2012). However, no significant differences were established between samples, $2^{\text {nd }}$ series samples showed the higher scores in the degree of flavour liking.

Structure. Statistical analysis of the data have shown that there are significant differences between $1^{\text {st }}$ and $2^{\text {nd }}$ series samples in the terms of the assessment of the degree of structure liking. The evaluation of structure liking of $1^{\text {st }}$ series samples is $4.17 \pm 0.70$ within the hedonic scale range from "like a little" to "like extremely". In turn, the estimation of $2^{\text {nd }}$ series samples is within scale range from "neither like nor dislike" to "like a little".

Taste. There are no significant differences between the samples in terms of evaluation of the degree of taste liking; the evaluators liked both samples equally well. The taste rating of $1^{\text {st }}$ series samples is $4.10 \pm$ 0.83 and $2^{\text {nd }}$ series samples is $3.95 \pm 0.77$, respectively, within the hedonic scale range from "neither like nor dislike" to "like a little". The panellists indicated that $2^{\text {nd }}$ series samples had pronounced flavour properties, but at the same time samples were characterized with slightly acid taste which established the overall evaluation of the degree of taste liking.

\section{Conclusions}

The presence of Listeria monocytogenes had not been established in the samples which indicates that the producer properly applies a hurdle technology in fermented sausage production.

The special emphasis should be paid on the acidification process during fermented sausage production which could eliminate the growth of Listeria monocytogenes.

The overall quality indices of fermented sausages, especially $\mathrm{pH}$, water and salt content, have strong influence on taste, flavour, structure and appearance liking.

Fermented sausages with glucono-delta-lactone during 3 weeks of drying can achieve corresponding safety criteria and sensory properties for semidry fermented sausages.

\section{References}

Brusa, V., Prieto, M., Campos, C.A., Epszteyn, S., Cuesta, A., Renaud, V., Schembri, G., Vanzini, M., Michanie, S., Leotta, G., Signorini, M. (2020). Quantitative risk assessment of listeriosis associated with fermented sausage and dry-cured pork shoulder consumption in Argentina. Food Control, Article 107705.

European Commission No 2073/2005 of 15 November 2005 on microbiological criteria for food stuffs. Official Journal of the European Union, L338.

FAO (2013). Small-scale sausage production.

Feiner, G. (2006). Raw fermented salami. In G.Feiner (ed.), Meat products handbook. Practical science and technology (pp. 314-375). Woodhead Publishing Limited.

Hu, Y., Zhang, L., Zhang, H., Wang, Y., Chen, Q., Kong, B. (2020). Physicochemical properties and flavour profile of fermented dry sausages with a reduction of sodium chloride. LWT-Food Science and Technology, 124, Article 109061.

Lazic, I.B., Jovanovic, J., Simunovic, S., Raseta, M., Trbovic, D., Baltic, T., Ciric, J. (2019). Evaluation of sensory and chemical parameters of fermented sausages. Meat Technology, 60(2), 84-90. DOI: 10.18485/meattech.2019.60.2.2

Lucke, F. (1985). Fermented sausages. In B.Wood (ed.), Microbiology of Fermented Foods, Vol. 2. (pp. 41-84). Elsevier.

Mataragas, M., Bellio, A., Rovetto, F., Astegiano, S., Decatelli, L., Cocolin, L. (2015). Risk-based 
control of food-borne pathogens Listeria monocytogenes and Salmonella enterica in the Italian fermented sausage Cacciatore and Felino. Meat Science, 103, 39-45.

Meloni, D. (2015). Presence of Listeria monocytogenes in Mediterranean style dry fermented sausages. Foods, 4 (1), 34-50.

Prado, N., Sampayo, M., Gonzalez, P., Lombo, F., Diaz, J. (2019). Physicochemical, sensory and microbiological characterization of Asturian Chorizo, a traditional fermented sausage manufactured in Northern Spain. Meat Science, 156, 118-124.

Ricke, S.C., Keeton, J.T. (1997). Fermented meat, poultry and fish products. In M.P.Doyle, L.R.Beuchat, T.J.Montville (eds.), Food Microbiology: Fundamentals and Frontiers (pp. 610-628). ASM Press.

Silins, I. (2014). The effects of $\mathrm{pH}$, aw and lactic acid bacteria on Listeria monocytogenes in fermented sausages. In FoodBalt: $9^{\text {th }}$ Baltic conference on food science and technology "Food for consumer well-being.”, 8-9 May 2014 (pp. 55-60). Jelgava: Latvia University of Agriculture.

Stiebing, A., Rödel, W. (1988). Influence of relative humidity on the ripening of dry sausages. Fleischwirtshaft, 68, 1287-1291.

Tabanelli, G., Coloretti, F., Chiavari, C., Grazia, L., Lanciotti, R., Gardini, F. (2012). Effects of starter cultures and fermentation climate on the properties of two types of typical Italian dry fermented sausages produced under industrial conditions. Food Control, 26, 416-426.

Thevenot, D., Delignette-Muller, M.L., Christieans, S., Vernozy-Rozand, C. (2005). Fate of Listeria monocytogenes in experimentally contaminated French sausages. International Journal of Food Microbiology, 1001, 189-200.

Tirloni, E., Di Pietro, V., Rizzi, G., Pormilio, F., Cattaneo, P., Bernandi, C., Stella, S. (2019). Non-thermal inactivation of Listeria spp. in a typical dry-fermented sausage: Bergamasco salami. Italian Journal of Food Safety, 8(3), 8112.

\section{Acknowledgement}

The present research has been conducted by Ādažu desu darbnīca Ltd. with the financial support from the European Regional Development Fund (contract No. 1.2.1.1/18/A/002) within the framework of the project of Latvian Food Competence Centre (01.06.2019.). 